\title{
PARTICIPATION OF THE PRESIDENTS WOJCIECH JARUZELSKI AND LECH WAŁĘSA IN THE PROCESS OF CABINET FORMATION IN POLAND
}

\author{
by Krystyna Leszczyńska
}

\section{PARTICIPATION OF WOJCIECH JARUZELSKI, THE PRESIDENT, IN THE PROCESS OF CABINET FORMATION IN POLAND}

\section{MISSION OF CZESEAW KISZCZAK}

On July 2, 1989 Mikołaj Kozakiewicz, the Speaker, informed Members of Parliament that he received, from the President of the Polish Peoples' Republic Wojciech Jaruzelski, motion for appointing general Czesław Kiszczak to a post of Prime Minister. ${ }^{1}$

It should be stressed that at the beginning of political transformation in $\mathrm{RP}$ as a result of the amendment to the Constitution from April 7, $1989^{2}$ so called April amendment the head of state gained exclusive competence to put forward a motion for appointment or cancellation of prime minister to the Sejm. The Prime Minister could present the first Chamber

\footnotetext{
1 Stenographic report from $4^{\text {th }}$ Sejm meeting on August 2, 1989, columns 204-209.

2 See Act from April 7, 1989 about the Constitution of the Polish Peoples' Republic (“Law Gazette" 1989, no 10, item 101).
} 
a motion concerning appointment and cancellation of government but after previous agreement with the President. Although the Sejm could not agree on the candidate of the head of state but it could not appoint a different person than the one appointed by the President. The crucial fact was that the above regulation excluded the ability of forming a Cabinet whose political orientation and personal composition was not accepted by the First Person in the State. The President could, after consultations with the Speaker of the Sejm and the Marshal of the Senate, dissolve a Parliament if within three months it was impossible to form a government. According to Tadeusz Mołdawa, the solutions accepted in April amendment were incorrect because they favoured "a complete constitutional blockade in appointing government if both parties that took part in this process, even after successive parliamentary elections, were unable to form an agreement."3

General C. Kiszczak stated in the Sejm that his candidature might be a surprise because of his previous activity; but his long lasting political, state, and organizational-managing experience and the success of "the round table" talks made him accept the above proposition. ${ }^{4}$

In the group connected with "Solidarity" there were intensive discussions concerning the political construction of government. As a result, they accepted the slogan "your president, our prime minister" that was formed by Adam Michnik in July $1989^{5}$ although at first this slogan was regarded as "his own" opinion. ${ }^{6}$

On August 2, 1989 the Sejm appointed C. Kiszczak for the post of the Prime Minister and charged with a task of forming a Cabinet and its personal composition. 420 deputies took part in voting concerning appointing the new Prime Minister (237 were for, 173 were against and 10 MPs abstained from voting). ${ }^{7}$ Czesław Kiszczak was the third candidate

3 T. Mołdawa, Legislatywa i egzekutywa pod rzadami noweli kwietniowej i Małej Konstytucji, [in:] Zmiany systemu politycznego w Polsce, ed. E. Zieliński, Warszawa 1993, p. 207.

4 Stenographic report from the $4^{\text {th }}$ Sejm.

5 A. Michnik, Wasz prezydent, nasz premier, “Gazeta Wyborcza”, July 3, 1989, p. 1

6 Geremek opowiada, Żakowski pyta, Rok 1989, Warszawa 1989, p. 227.

7 PAP, “Rzeczpospolita”, August 3, 1981, no. 180, p. 1. 
for the Prime Minister. Previously, W. Jaruzelski proposed this function to Władysław Baka ${ }^{8}$ then to Roman Malinowski (the President of NK ZSL-United Peasants' Party). ${ }^{9}$ Both rejected the proposition. ${ }^{10}$ In the article published in "Gazeta Wyborcza" in 2008 C. Kiszczak stated that at first he also refused. But the argument that - I am not an economist - did not convince W. Jaruzelski. ${ }^{11}$ According to the then President, C. Kiszczak's merits in forming the debates of "the round table" were to guarantee him the acceptation of the opposition. ${ }^{12}$ In spite of wide variety of activities directed to form a Cabinet, the representative of PZPR [Polish United Peoples' Party] was not able to form it. The failure of C. Kiszczak's mission resulted, first of all, from the attitude of opposition that expressed the rule "all or nothing" and did not want to join the government. ${ }^{13}$ On August 7, 1989, Lech Wałęsa issued a statement in which he wrote that the decisions concerning the nomination of a new Prime Minister deepened the confidence crisis, showed that economic monopoly would not change and supported people's fears that nothing changed in Poland. ${ }^{14}$ The above quoted arguments the leader of "Solidarity" supported with the following words " $(. .$.$) once again I am against the formation of the new government$

8 Władysław Baka, prof. dr hab. of economics. From July 3, 1981 to November 12, 1985 he was a minister - member of the Cabinet, Government plenipotentiary for economic reform. From November 26, 1983 to November 15, 1985 he functioned as minister - member of government board. See W. Styczyński, Guide book for Personal Organization of State Managerial Posts in Offices of Main State Administration Organs during the period from July 21, 1944 to September 11, 1989. Prime Minister's Office, Warszawa 2000, p. 343.

9 Roman Malinowski, PhD of economics. From April 3, 1980 to November 6, 1985 was vice Prime Minister. From April 3, 1980 to October 8, 1980 he was at the same time the Minister of Food Industry and Purchase. See ibidem, p. 466.

10 Abort Prime Minister's Election and New Government. The Speaker before TV Cameras, "Rzeczpospolita", August 10, 1989, no.186, pp. 1-2.

11 1988. The Truth according to General Kiszczak. Document. The Report of Former Head of MSW., "Gazeta Wyborcza”, August 22-24, 2008, no. 197, p. 26.

12 K.B. Janowski, Źródła i przebieg zmiany politycznej w Polsce (1980-1989), Historical-Political-Science Study, Toruń 2004, p. 322.

13 R. Kondrat, Przed utworzeniem, R.M. Wielka czy mała koalicja?, "Rzeczpospolita", June 5, 2008, no. 182, pp. 1-2.

14 L. Wałęsa, Droga do prawdy. Autobiografia, Warszawa 2008, p. 297. 
by Czesław Kiszczak. The only political solution is the formation of the Cabinet by a coalition "Solidarity «, ZSL and SD [Democratic Party]. And I will strive for it." 15 There is no doubt that putting forward a motion for appointing general C. Kiszczak for the post of Prime Minister was the wrong personal decision of the then Head of State and hastened the fall of PZPR [Polish United Workers' Party] rule. According to Antoni Dudek "entrusting Kiszczak with the mission of forming the cabinet had disastrous propaganda effect and inevitably was connected with carousel of posts." 16 Besides, social moods and expectations were not taken into consideration and it was seen in the results of Parliamentary election from June 1989. ${ }^{17}$

\section{THE CABINET OF TADEUSZ MAZOWIECKI}

On August 17, 1989 during the meeting at President W. Jaruzelski, the leader of "Solidarity presented the concept of forming a coalition government of national responsibility that would consist from all pro-reform political powers represented in the Sejm."18 Realization of decisions undertaken during the debate of "The Round Table" was to be the aim of the Cabinet. ${ }^{19}$ According to R. Malinowski the President W. Jaruzelski did no oppose that. "Subdued and stooped" he listened to the declarations presented by L. Wałęsa. ${ }^{20}$ In this situation the mission of forming the new Cabinet (in accordance with the concept of the leader of "Solidarity") was given to T. Mazowiecki. It should be stressed that nomination for this

\footnotetext{
15 Ibidem, p. 297.

16 A. Dudek, Pierwsze lata III Rzeczypospolitej. 1989-2001, Kraków 2002, p. 69.

17 As the result of parliamentary elections, that were held on 4th and 18th June 1989, "Solidarity" won 161 seats in the Sejm (35\% of seats) and 99 seats in the Seanate. It should be stressed that "Solidarity" won the maximum number of seats described in the so called contract of "the Round Table". See: M. Chmaj, Sejm kontraktowy w transformacji systemu politycznego Rzeczpospolitej Polskiej, Lublin 1996, p. 74.

18 PAP, Zapowiedź rządu koalicji narodowej, "Rzeczpospolita”, August 18, 1989, no. 191, pp. 1-2.

19 Statements of the leaders of „Solidarity”, ZSL and SD, “Rzeczpospolita”, August 18, 1989, no. 191, pp. 1-2.

20 R. Malinowski, Wielka koalicja. Za kulisami, Warszawa 1992, pp. 30-31.
} 
post the candidature of former MP, trustee of Church and editor-in chief of "Tygodnik Solidarność" [Solidarity Weekly] was put forward after considering his previous experience in legislative field and his abilities for compromise. ${ }^{21}$ But this decision caused sensation both in Poland and abroad - the Prime Minister from opposition. It was a very important and at the same time symbolic event - W. Jaruzelski, member of PZPR [Polish United Workers' Party] and general nominates for the post of prime minister T. Mazowiecki a member of 'Solidarity". "The authorities" without bloodshed gave away their power! The Prime Minister C. Kiszczak resigned and the Sejm accepted the resignation on August 24, 1989. There was no voting. The Speaker of the Sejm announced that if he did not hear any voice of objection he would regard that the members of parliament accepted both the motion put forward by C. Kiszczak and the President's request. There was silence in the council chamber. ${ }^{22}$ At the same day lower chamber appointed Tadeusz Mazowiecki for the post of prime minister and entrusted him with the presentation of the personal composition of the Cabinet. ${ }^{23}$ Almost $90 \%$ voters supported the new prime minister.

The new prime minister conducted extensive consultations with politicians, party and parliamentary clubs leaders. As T. Mazowiecki recalls "the conversation with the President was very sincere. He assured help from the apparatus of the state, army and secret police." 24 On September 12, 1989 the Sejm voted over the appointment of the Cabinet of Tadeusz Mazowiecki. 415 members of parliament took part in it ( 404 were for, nobody voted against and 13 MPs abstained from voting). ${ }^{25}$ The Cabinet

\footnotetext{
21 1988. Prawda wedtug generała..., p. 26; M. Sandecki, Będę ciąt siekiera, Part 5, “Gazeta Wyborcza”, July 4, 2008, no. 155, p. 20.

22 Stenographic report from $6^{\text {th }}$ Sejm meeting on August 24, 1989, columns 81-82.

23 Ibidem, column 98.

24 Prime Minister Tadeusz Mazowiecki. I must Hurry, “Gazeta Wyborcza”, August 25, 1989 , no. 77 , p. 5 .

25 See: Stenographic report from $7^{\text {th }}$ Sejm meeting on September 12, 1989, column 47.
} 
of T. Mazowiecki gained support of the majority of members of the first chamber because it was composed from members of all political powers presented in the Sejm. ${ }^{26}$

\section{PARTICIPATION OF LECH WAŁĘSA IN THE PROCESS OF CABINET FORMATION}

\section{THE CABINET OF JAN KRZYSZTOF BIELECKI}

On November 27, 1990, after the first round of presidential elections in which L. Wałęsa and S. Tymiński won the greatest support, T. Mazowiecki who took part in the elections submitted a motion to the Speaker, M. Kozakiewicz to dismiss his Cabinet. ${ }^{27}$ This meant that he rejected the proposition of L. Wałęsa concerning the post of prime minister in case the leader of "Solidarity" would be the head of state. T. Mazowiecki thought that in this case he would lose his independence and he was convinced that L. Wałęsa was not competent for the post of the president. ${ }^{28} \mathrm{On}$ December 14, 1990 the Sejm dismissed T. Mazowiecki's Cabinet and charged him with fulfilling the duty until the appointment of the new Cabinet. ${ }^{29}$

Who would be the head of a new government and what would be its composition was the subject of discussions during election campaign. People centered around Lech Wałęsa suggested the following candidatures after he would win the election: Jan Krzysztof Bielecki, Jarosław Kaczyński, Jacek Merkel, Zdzisław Najder or Jan Olszewski. On December 2, 1990 L. Wałęsa (even before the second round of election) empowered J.Olsze-

\footnotetext{
26 There were 12 representatives of "Solidarity" (50\% of posts), 4 members of PZPR, 4 members of ZSL, 3 members of SD and 1 that did not belong to any political group. The Cabinet was formed on September 12, 1989.

27 The Sejm will Examine the Motion, "Rzeczpospolita", November 28, 1990, no. 277 , p. 1 .

28 M. Sandecki, Będę ciat siekiera...,p. 22.

29 See: Stenographic report from $46^{\text {th }}$ Sejm meeting on December 14,1990 , column 188 .
} 
wski to conduct preliminary talks concerning the programme and composition of a new cabinet. J. Olszewski held consultations with many people. But the vision of the composition of his cabinet was basically different from the vision of L. Wałęsa. And on December 18, 1990 J. Olszewski resigned from his mission. ${ }^{30}$ President-elect wanted to form the Cabinet of specialists, young and dynamic experts. ${ }^{31} \mathrm{~J}$. Olszewski also was after the government of specialists - people who were competent and had social authority but absolutely different from the Cabinet of T. Mazowiecki. ${ }^{32}$ After 18 years Lech Wałęsa stated: "I had a different concept because I felt that Mr. Olszewski - whom I admire and hold in high esteem up till now for his activity during communism - was not the best candidate for this post. (We experienced this when he became the Prime Minister)." 33

Just before swearing into the office of the Head of the State, L. Wałęsa announced that he was going to take cautious decisions concerning formation of the government and presented two scenarios of future political solutions. First version: president-elect suggested the shift of the date of parliamentary elections at least by one year; he wanted to give the prime minister and his government time to show what they had done. The second version: he did not dismiss the "old" Cabinet that would, after some necessary changes, survive till the spring parliamentary elections. ${ }^{34}$

At the end of 1990, the President L. Wałęsa conducted in Belvedere very intensive talks concerning formation of the Cabinet. ${ }^{35}$ On December 29 he put the motion in the Sejm concerning appointing J.K. Bielecki for the post of the Prime Minister. The motion was accompanied by a very laconic CV of the candidate; it comprised the information about his age, marital status,

30 B. Jaworowska, J.R. Kowalczyk, Jan Olszewski zrezygnowat, “Rzeczpospolita”, December 19,1990 , no. 295 , p. 1.

31 Ibidem.

32 K. Groblewski, Miał to być gabinet fachowców. Kazimierz Groblewski w rozmowie z Janem Olszewskim, “Rzeczpospolita”, December 20, 1990, no. 296, pp. 1-2.

33 L. Wałęsa, Droga do prawdy..., p. 353.

34 D.P. PAP, Kiedy rzą, kiedy parlament. Dwie propozycje L. Wałęsy, "Rzeczpospolita", December 21, 1990, no. 297, pp. 1-2.

35 K. Groblewski, Ruch w Belwederze. Spotkanie Wałesa-Mazowiecki, "Rzeczpospolita", December 28, 1990, no. 300, pp. 1-2. 
number of children, education, political membership and his parliamentary duties. ${ }^{36}$ According to L. Wałesa the candidature of up till now unknown to wider circles J.K. Bielecki was to bring "(...) a breeze of freshness from Pomeranian district, infusion of new energy. Jan Krzysztof was a young, promising, dynamic activist and manager. We needed somebody like him. I gave Poland a signal: economy first. Bielecki represented a new liberal circle. Only such people could put in motion market economy (...)." ${ }^{37}$ According to the head of state J.K. Bielecki was brave, intelligent and did not belong to the circles entangled in "Warsaw" elite. This nomination was, according to Wałęsa, a symptom of new, trouble-free formation of government which consisted in including in it a few ministers from T. Mazowiecki Cabinet. ${ }^{38}$ In this way, L. Wałesa opened, to unknown earlier economist from Gdańsk, a road to European establishment. ${ }^{39}$

On January 4, 1991 the Sejm of the Republic of Poland passed a resolution concerning the nomination of J.K. Bielecki for the post of the Prime Minister and charged him with the presentation of motions concerning the personal composition of the government. ${ }^{40}$ Journalists from "Gazeta Wyborcza" described J.K. Bielecki as "a man who up till now did not show a strong political personality, he was a representative of a small political party with insignificant Parliamentary representation." ${ }^{11}$ When A. Michnik asked J.K. Bielecki: "What are your relations with the President?", he answered: "Since I took this office »unexpectedly« he must have trusted me; maybe it was his great political instinct. My principal rule is to lead our country in a very settled way to the first free elections. Hence there appeared a saying »from line to line«. I think that our relations are exem-

${ }^{36}$ In the motion L. Wałęsa wrote: "Mr. Jan Krzysztof Bielecki, age 39, married, two children - is an economist, activist of "Solidarity « for many years. He is also a member of the Board of the Liberal-Democratic Congress and member of Parliament of the Sejm of the $10^{\text {th }}$ term." See Stenographic report from the $48^{\text {th }}$ Sejm sitting on January 4,1991 , column 10 .

37 L. Wałęsa, Droga do prawdy..., p. 354.

38 Ibidem, pp. 354-355.

39 A. Basta, Rząd na danie główne, Toruń 2008, p. 19.

40 See: Stenographic report from the $48^{\text {th }}$ Sejm sitting on January 4, 1991, column 23.

41 K. Leski, P. Ławinski, Bielecki na prezydenta, "Gazeta Wyborcza”, January 2, 1991, no. 1, p. 1. 
plary because I, from my part, guarantee elementary feeling of responsibility and loyalty to the President and the President gives me a lot of freedom contrary to what journalists at the beginning said, when they thought that everything was arranged by the Belvedere or Lech Wałęsa. I am independent in my decisions - the president even did not know who would be in the Polish government." 42

On January 12, 1991 the Sejm appointed the Cabinet J.K. Bielecki. 272 members of Parliament were for, 4 against and 62 abstained from voting. ${ }^{43}$ The Prime Minister received 4 voices more than the Cabinet; the cabinet was disapproved by 54 MPs less than the Prime Minister. The Members of Parliament who approved the cabinet constituted $80 \%$ of the voters. Majority of the MPs thought that it was the government of the head of state. $^{44}$

\section{THE CABINET OF JAN OLSZEWSKI}

As a result of parliamentary elections from October 27, 1991 the Sejm was represented by 29 political parties none of which won $50 \%$ of seats. ${ }^{45}$ The candidature of Jan Olszewski was introduced for the first time on November 7, 1991.46 A week later, the leaders of five parties Porozumienie Centrum [PC - Centre Agreement], Zjednoczenie ChrześciańskoNarodowe [ZChN - Christian-National Union], Kongres LiberalnoDemokratyczny [KLD - Liberal Democratic Congress], Konfederacji

42 We Reed an Agrement of Reasonable People. Adam Michics Talks with the Prime Minister J.K. Bielecki, “Gazeta Wyborcza”, October 19-20, 1991, no. 245, p. 11.

43 See: Stenographic report from the $49^{\text {th }}$ Sejm sitting on January 12, 1991, columns 153-154.

44 J. Poprzeczko, Łącznik z Gdańska. Nowy premier - rząd odnowiony, "Polityka", January 12, 1991, no. 2, p. 7.

45 Democratic Union received the best result. But the electoral success had a very bitter taste because DU won only 62 seats in the Sejm. The second was the Alliance of Democratic Left with 60 seats. The number of seats of the rest political groups was very different: from 49 to 1 . As many as 11 groups had only one representative. See: K. Leszczyńska, Rządy Rzeczpospolitej polskiej (1989-2005), Toruń 2008, p. 56.

46 S. Patyra, Rząd Jana Olszewskiego, [in:] Gabinety koalicyjne w Polsce w latach 1989-1996, eds. M. Chmaj and M. Żmigrodzki, Lublin 1998, p. 77. 
Polski Niepodległej [KPN - Confederation of Independent Poland] and solidarity Porozumienie Ludowe [PL - Peasants Agreement] presented his candidature to the head of state. But the President who supported J.K. Bielecki ${ }^{47}$ did not want to accept J. Olszewski to the post and his cabinet of "change" because he did not believe him. He said that "the only strong side" of this candidature was "good and frequent sleep".48 On the other side the coalition of central-right parties did not want J.K. Bielecki to take the office of the prime minister. ${ }^{49}$ In this situation the head of the cabinet decided that he would resign at the first meeting of the Sejm. The President appealed to him to give up his idea. ${ }^{50} \mathrm{~J} . \mathrm{K}$. Bielecki did not give in to this suggestion and tendered his resignation to the Speaker. Lech Wałesa appealed to W. Chrzanowski to reject this motion. He pointed for the need of enacting a new constitution ( L. Wałęsa was to present its project) and suggested that the new government should be called after passing it. ${ }^{51}$ The head of state opted for widening the coalition; this coalition was a guarantor of forming majority government. The coalition "five" ensured L.Wałesa in writing that it had parliamentary majority in parliament. Because W. Chrzanowski supported the constitutional initiative of the President, the case of government dismissal was suspended till December 5, 1991.52 Porozumienie Centrum was prone to fulfill the President's postulate and widen the coalition with Unia Demokratyczna [Democratic Union] (that had the best result) but the candidate for the post of Prime Minister did not agree for that. ${ }^{53}$

47 (ard, Ław. wz), Olszewski - the candidate of the five. The President prefers Bielecki. Democratic Union Returns to the Game?, "Gazeta Wyborcza", November 15, 1991, no. 271 , p. 60 .

48 L. Wałęsa, Moja III RP. Straciłem cierpliwość, Warszawa 2007, p. 60.

49 (knysz), "Gazeta Wyborcza”, November 21, 1991, no. 271, p. 1.

50 (A), Dymisja rządu mimo apelu Wałęsy, "Gazeta Wyborcza”, November 23-24, 1991, no. 273, p. 1.

51 (A), Stary rząd, nowa konstytucja, “Gazeta Wyborcza”, November 26, 1991, no. 275 , p. 1 .

52 (aj,wz), Prezydent: najpierw mała konstytucja "piątka”: Olszewski tuż, tuż, "Gazeta Wyborcza", Novemeber 28, 1991, no 277, p.1.

53 S. Patyra, Rząd Jana Olszewskiego...., p. 79 
On November 28, 1991 J. Olszewski presented the concept of over-party government of professionals to the groups that supported him. ${ }^{54}$ The President still did not want to accept the candidature of these five parties. L. Wałęsa thought that J. Olszewski was "a candidate".55

But since, on December 5, 1991, the Sejm accepted the dimission of the Cabinet of J.Bielecki ${ }^{56}$ the head of state had to stop "playing for time" and had to start the procedures of appointing J. Olszewski for the post of the Prime Minister. In his motion L. Wałęsa wrote that J. Olszewski was a candidature of five political parties and that he accepted the choice and that he would respect the rules of democracy. ${ }^{57} \mathrm{~L}$. Wałęsa agreed for J. Olszewski because he was sure that the mission of forming the cabinet would fail..$^{8}$

On December 6, 1991 the Sejm appointed J. Olszewski for the post of the Prime Minister. ${ }^{59}$

The new Prime Minister announced that his Cabinet would be an overparty one and it would be based on a firm political grounds. ${ }^{60}$ "It should be the government of authorities, content-related, professional and also moral authorities. It should be the government of moral credibility because the Cabinet that would demand from the society had to be above any suspicions as far as its intentions were concerned. It should be the government of clear intentions and clean hands." ${ }^{61}$

54 Rząd ponadpartyjny, “Gazeta Wyborcza”, Novemeber 29, 1991, no. 278, p. 1.

55 A. Kublicaka, Ludzie prezydenta kontra prezydent, "Gazeta Wyborcza”, December 3, 1991, no. 281, p.1.

56 See: Stenographic report from the $1^{\text {st }}$ Sejm sitting on December 4, 1991, p. 129. Since the 56 Sejm sitting on April 18, 19 and 20, 1991 there was a change in stenographic reports. Pages replaced columns.

57 Ibidem, p.130.

58 A. Dudek, Pierwsze lata..., pp. 232-233.

59 Stenographic report from the $1^{\text {st }}$ Sejm sitting on December 4, 1991, p.191; Also see: p. 193 where there is a correction: not 57 MPs were against J. Olszewski but only 47.

60 See: Stenographic report from the $1^{\text {st }}$ Sejm sitting on December 6, 1991, p. 189.

61 Ibidem. 
The declaration of the head of the government led to a very serious political crisis. ${ }^{62}$ Since the "coalition five" broke down and L. Wałęsa still did not approve the cabinet, J. Olszewski resigned from the mission of forming his cabinet. ${ }^{63}$ A stormy debate concerning the acceptance of his resignation was conducted in the Sejm. ${ }^{64}$ But the resignation was not accepted (132 MPs were for, 214 - against 73 - abstained from voting) ${ }^{65}$ After this, the President L. Wałęsa offered J. Olszewski versatile help both in the process of construction of the cabinet and also after its rise. Frequent meeting of the head of state and the head of the government were agreed on. Although the President gave J. Olszewski 50\% in forming the Cabinet, he regarded it as promising. ${ }^{66}$ According to L. Wałęsa, J. Olszewski would not manage to form over-party government that was confirmed by the facts and style of managing. It should be stressed that the President L. Wałęsa did not interfere in the personal appointments of the so called strategic departments i.e. MSW (Ministry of Internal Affairs] MSZ [Ministry of Foreign Affairs], MON [Ministry of National Defence]. ${ }^{67}$ On December 23, 1991 the Sejm appointed J. Olszewski for the post of the Prime Minister (235 deputies were for, 60 against, 139 - abstained from voting). ${ }^{68}$ Only $54 \%$ of voters supported the Cabinet. None of the previous Cabinets after 1989 received such a low support.

62 S. Patyra, Rząd Jana Olszewskiego..., p. 79.

63 (ard,wz), Olszewski zrezygnowat, "Gazeta Wyborcza”, December 18, 1991, no. 294 , p. 1.

64 See: Stenographic report from the $2^{\text {nd }}$ Sejm sitting on December 17-18, 1991, pp. 38-49.

65 See ibidem, p.51.

66 (aj, wz knysz), Sejm chce Olszewskiego, "Rzeczpospolita”, December 19, 1991, no. 295 , p. 1 .

67 L. Wałęsa, Droga do prawdy..., p. 372.

68 See: Stenographic report from the $4^{\text {th }}$ Sejm sitting on December 23, 1991, p. 28. 


\section{THE MISSION OF WALDEMAR PAWLAK}

The Cabinet of J. Olszewski collapsed at night from June 4-5, 1992.69 On May 28, 1992 the Sejm accepted, beyond the agenda, the resolution ${ }^{70}$ concerning disclosure of collaborators of secret police (SB) from 1945-1990, the minister of Interior and Administration - Antoni Macierewicz, on June 4, 1992 delivered the highest state authorities two lists of names of members of parliament and high rank state officials who, according to Ministry of Internal Affairs were secret police (SB) agents. Although the Ministry spokesman immediately stated that those were only information about materials not lists of agents ${ }^{71} \mathrm{~L}$. Wałęsa who was on one of those lists under code name "Bolek" submitted a motion for immediate dismissal of J. Olszewski government: "I was forced to move a motion for immediate dismissal of such incompetent government on June 4, 1991; it wanted to defend itself by jeopardizing Poland and its institutions. It would be a discredit of the idea of inspection and it was confirmed later. Let me remind that the motion for the dismissal was already submitted and the Sejm was to vote over it in any case."72 On June 5, 1992 the President submitted the motion for appointing for the post of prime minister a 33 year old politician Waldemar Pawlak. ${ }^{73} 417$ deputies took part in the voting (261 were for, 149 were against and 7 abstained from voting). ${ }^{74}$ Probably this candidatures was recommended by prof. Janusz Ziółkowski, secretary of State from the President's office. ${ }^{75}$ There is no doubt that through this decision L. Wałęsa wanted to ensure himself W. Pawlak's compliance and availability. It should be stated that W. Pawlak was the youngest Polish Prime Minister since the World War II. ${ }^{76}$

69 See: Stenographic report from the $17^{\text {th }}$ Sejm sitting on June 4, 1992, p. 82.

70 M.P. no.16, item 116.

71 Teczki zostały rzucone. Rzą Jana Olszewskiego odwołany, “Gazeta Wyborcza”, June 5, 1992, no. 132, p. 1.

72 L. Wałęsa, Droga do prawdy...,.p. 401.

73 See: Stenographic report from the $17^{\text {th }}$ Sejm sitting on June 5, 1992, p. 83.

74 Ibidem, p. 83.

75 A. Basta, Rząd na główne..., p. 19.

76 Eg. Edward Osóbka Morawski was 35 years and Józef Cyrankiewicz 36. See: W. Styczyski, Informator o organizacji... 
On June 6 the Speaker W. Chrzanowski handed W. Pawlak nomination document for the post of Prime Minister. The new Prime Minister appointed Janusz Onyszkiewicz (DU) for the post of the minister of National Defence, Andrzej Milczanowski (non-party) for the head of Ministry of Internal Affairs. ${ }^{77}$ But in spite of intensive consultations, W. Pawlak did not manage to form the Cabinet. L. Wałęsa presented the concept of the so called presidential cabinet. According to his suggestion, five departments (Foreign Affairs, Agriculture, Industry, Finances and Economic) should be run by the heads (in the rank of secretary of undersecretary of state). W. Pawlak did not support this concept; he said that there was a possibility to form the cabinet by parliament majority. ${ }^{78}$ Since his activities did not bring any results and he was not able to from a cabinet, the Sejm dismissed him from the post of prime minister on July $10,1992 .{ }^{79}$

\section{THE CABINET OF HANNA SUCHOCKA}

When it became clear that W. Pawlak would not be able to form a cabinet, Democratic Union presented its own candidature: "Someone from television mentioned in the backstage at Wiejska the name of Hanna Suchocka. MPs smiled The next day the Democratic Union put forward her candidature for the post of prime minister." 80 All members of coalition talks agreed on "the prime minister - a woman". The President whose attitude was then not known described this candidature as "interesting." It can be assumed that at the beginning he did not treat her seriously because he asked W. Pawlak to appoint the heads of »main departments that are necessary for functioning of the state «." ${ }^{11}$ Hanna Suchocka commented upon her nomination in this way: "Maybe the facts that I have

\footnotetext{
77 Ibidem, pp. 56-58.

78 Ibidem, pp. 75-76.

79 See: Stenographic report from the $20^{\text {th }}$ Sejm sitting on July 10, 1992, p. 4.

80 A. Metelska, A. Niedzielska, Hanna Suchocka. Pani Premier, “Twój Styl” 1992, no. 10 , p. 12 .

81 E. Szemplińska, Skazana na władzę. Wyborem nowego kandydata na premiera najbardziej zaskoczona była Hanna Suchocka, "Wprost” 1992, no. 29, p. 19.
} 
never been a politician from first pages and that I have not taken part in parliamentary intrigues were decisive factors - my candidature was not so much controversial." 82 It should be stressed that consultations concerning the formation of the cabinet were led by parties whose representatives were to join the government. Jan Rulewski from Parliamentary Solidarity Club was a very successive negotiator. It also should be noted that Hanna Suchocka did not take part in the cabinet formation. ${ }^{83}$ It was caused by the fact that H. Suchocka became the prime minister as a result of political negotiation i.e. a kind of logical calculation. She did not win the elections as Margaret Thatcher (the Prime Minister of Great Britain or Sirimavo Bandaranaike (the Prime Minister of Sri Lanka). ${ }^{84}$ On July 10 the Sejm appointed H. Suchocka for the post of the Prime Minister. ${ }^{85}$ The new Prime Minister presented the Sejm with outlines of the works of her Cabinet and its personal composition ${ }^{86}$ (the programme tasks and rules of Cabinet's activity H. Suchocka delivered on October 9, 1992). ${ }^{87}$ The next day the first chamber voted to accept the cabinet of H. Suchocka (226 were for, 124 - against and 28 abstained from voting). ${ }^{88}$ The coalition that supported the Cabinet was described as: difficult, strange, exotic, responsible for Poland. ${ }^{89}$ The President declared that he "supported the Cabinet but when it disappointed him he would take power in his hands (...)."90 Besides, he said that he tried to give the new Cabinet a large credit of confidence but social discontent ${ }^{91}$ "made his look at the Cabinet of Hanna Suchocka with

82 M. Król, K. Pytko, E. Szemplińska, Przepis na władzę. Rozmowa z Hanna Suchocka, Prezesem rady Ministrów, "Wprost” 1992, no. 30, p. 13.

83 E. Szemplińska, Skazana..., pp. 19-20.

84 See: K.Leszczyńska, Rządy Rzeczpospolitej Polskiej..., p. 4.

85 Stenographic report from the $20^{\text {th }}$ Sejm sitting on July 10, 1992, p. 4.

86 See: Stenographic report from the $20^{\text {th }}$ Sejm sitting on July 10, 1992, pp. 15-19.

87 See: Stenographic report from the $20^{\text {th }}$ Sejm sitting on October 9, 1992, pp. 121-127.

88 See: Stenographic report from the $20^{\text {th }}$ Sejm sitting on July 11, 1992, p. 60.

89 J. Paradowska, Zasępieni hamleci. Rząd siódemki czy „trójkąt bermudzki” małej koalicji?, "Polityka" 1992, no. 29, p. 5.

90 M. Król, K. Pytko, E. Szemplińska, Przepis na władzę..., p. 13.

91 The number of demonstrations in 1992 rose by 6046 in relation to 1991 and amounted to 6351. In 1993 there were 7443 strikes and protest actions It should be 
caution."92 According to the president the Prime Minister's statements concerning cooperation with the head of state were of declarative character because she could not overcome political limits of her parliamentary club. ${ }^{93}$ His lack of confidence to the Prime Minister could be reflected in the fact that he took part in its first meeting which was held on July 14, 1992. After courteous congratulations the President expressed his will to be in regular contact. L. Wałęsa underlined the importance of experience that he gained during previous cabinets, pointed to the necessity of continuation of reforms started by previous cabinets and declared help in realization of state tasks. ${ }^{94}$ It seems that the president tried to define the principles of cooperation with the Cabinet of $\mathrm{H}$. Suchocka and settle the directions of its activity,

\section{THE CABINET OF WALDEMAR PAWLAK}

On May 19, 1993 a group of 52 MPs (from circles that at the beginning supported the Cabinet of woman-prime minister) lodged to the Speaker W. Chrzanowski vote of non-confidence to the cabinet of Hanna Suchocka. They justified it by the fact that the Cabinet only pretended to conduct negotiations with NSZZ Solidarity and hampered the enterprises from the ability to stop paying the tax from over-normative gratification in budget sphere (so called popiwek). ${ }^{95}$

On May 28, 1993 the Sejm of the Republic of Poland, in the presence of L. Wałęsa, decided to express the vote of non-confidence to the Cabinet of H. Suchocka 223 were for (that was an absolute magnitude ), 198 were against and 24 abstained from voting. ${ }^{96}$ The same day the Speaker informed

noted that the large number of strikes and protest actions took place during J. Olszewski rule and attempts to from the cabinet by Pawlak. They also took place during Pawlak's cabinet. See Labour market - table 17(210_ - Strikes, [in] Statystical Yearbook, Main Statistical office, Warszawa 1998, p. 139.

92 Olszewski odwołany, “Gazeta Wyborcza”, June 5, 1992, no. 132, p. 1.

93 L. Wałęsa, Droga do prawdy..., p. 419.

94 On the basis: Protocol of Decisions no 28 from the pitting of the cabinet on July 14, 1992, [AAJKPRM] no. sp.zd-o 2903/item31.

95 See: The sejm paper no 940.

96 Stenographic report from the $45^{\text {th }}$ Sejm sitting on May 28, 1993, p. 78. 
the MPs that he received a document from the President of RP in which the head of state notified that "...since the vote of non-confidence was enacted without appointing a new Prime Minister I start to perform my constitutional duties described in art. 66 of the act 5 of the Constitutional Act from October 17, 1992." 97

Early elections to the Sejm and Senate were the consequences of a dissolution of the parliament in which the majority of seats were won by SLD [Democratic Left Alliance] and PSL [Polish People's Party] ( together they had 303 seats in the Sejm and 73 in the Senate). When the results were announced the President said that the Left should be assessed. ${ }^{98}$ In spite of threats from the head of state the winning group started to form a firm parliamentary majority - able to form the cabinet. The coalition agreement, which SLD signed with PSL in October 1993, determined that the representative for the prime minister would be from PSL.W. Pawlak from PSL who at the end of September 1993 said that his party would not join the Cabinet administered by the prime minister from SLD became the candidate for this post. ${ }^{99}$ Kwaśniewski's party knew that it would be able to form a coalition if it agreed on conditions determined by PSL.

At the beginning L. Wałęsa did not engage himself in the process of cabinet formation and refused to talk with parties which negotiated its shape. Many things indicate that he did not want to be associated as a cobuilder of the cabinet SLD-PSL. ${ }^{100}$ But he did not stay inactive and he wrote a letter in which he demanded to present him three candidates for the post from whom he would chose one. The head of state decided that he needed such a solution "just in case" for the future. "Between me and Pawlak there is no conflict, but what happens after Pawlak? He is the best candidate for the prime minister but only when there is stability in the

97 Ibidem, pp. 78-79. Stenographic report from the $20^{\text {th }}$ Sejm sitting on October 9, 1992, pp. 121-127.

98 K. Leszczyńska, Socjaldemokraci w rządach III RP, [in:] Doktryna i ruch socjaldemokratyczny. Historia i współczesność, ed. E. Olszewski, Puławy 2001, pp. 429-431.

99 E.K. Czaczkowska, Inauguracyjne posiedzenie klubu. PSL chce premiera i marszałka, "Rzeczpospolita", October 1, 1993, no. 230, p. 2.

100 K. Groblewski, Jak prezydent tworzył rzady i jak powstawały same, "Rzeczpospolita", October 6, 1993, no. 234, p. 3. 
parliament and state. Today, the situation is so difficult that even the best prime minister, Lech Wałęsa will have difficulties. My friend Pawlak will not manage."101 The representatives of SLD, Leszek Miller and Zbigniew Siemiątkowski said that in the light of Small Constitution it was not necessary to present three candidates and they would not do it. The leader of the Alliance - Aleksander Kwaśniewski - declared that he would give an answer to "the request: of the head of state in a couple of days. ${ }^{102}$ SLD and PSL did not comply with Wałęsa's suggestion and presented only one candidate - W. Pawlak. On October 26, 1993, on the basis of art. 47 item 7 of the Constitutional Act from October 17, 1992 concerning mutual relations between legislative and executive powers and about territorial local government, ${ }^{103}$ so called Small Constitution, President designated W. Pawlak for the post of prime minister. ${ }^{104}$ It should be stressed that the representative of PSL was the first prime minister who after 1989 took this post without so called the influence of Lech Wałęsa. It is now legitimate to ask a question - Could Pawlak be able to become prime minister in 1993 if he was not granted the mission of cabinet formation in 1992? The answer is not unequivocal. But many things indicate that "the promotion" of W. Pawlak by L. Wałęsa in 1992 helped him to take the office of the prime minister in 1993. According to Piotr Winczorek the request of the head of state concerning presentation of three candidates was not illegal. But because it does not result from requirements described by Small Constitution from 1992, L. Wałesa was not legally obliged t present it. So the addressees were not obliged to subordinate to it. ${ }^{105}$ According to one of the commentators of Polish scene the request was an attempt to foresee the future relations with the coalition. ${ }^{106}$ On October 26, 1993 the members of the Cabinet with the Prime Minister were sworn into the office in

101 A. Wejner, Szach prezydentowi. Koalicjanci dali, "Wprost”, October 24, 1993, no. 43 , p. 11.

102 E.K., Prezydent-SLD Na razie bez odpowiedzi, "Rzeczpospolita", September 24, 1993, no. 224, p. 2.

103 "Law Gazette" no. 84, item 509.

104 See. M.P. 193, no 55, item 509.

105 P. Winczorek, Interpretacje, "Rzeczpospolita”, September 24, 1993, no. 224, p. 2.

106 K. Groblewski, Jak prezydent tworzył..., p. 3. 
Belvedere. On November 10, 1993 the Sejm gave the coalition SLD-PSL a vote of confidence. 417 deputies took part in voting (310 were for, 83 against and 24 abstained from voting). ${ }^{107}$

It should be stressed that L. Wałęsa, in accordance with his concept and on the basis of art. 61 of Small Constitution, introduced to the Cabinet the heads of strategic departments i.e. Ministry of Internal Affairs, Ministry of Foreign Affairs and National Defence. In the light of the above article, the Prime Minister should present the motion concerning the ministers of MIA, MFA, MNA after consultations with the president. According to Zbigniew Szeliga - "It is clear that this opinion does not bind the Prime Minister but it cannot be completely ignored because the ministers are appointed by the president." 108 There is no doubt that L.Wałęsa consciously "mixed up" the notions - opinion - with the right to recommendation - because he considered that Small Constitution gives him right to appoint the above mentioned ministers. The opinion do not have to be binding for the subject who takes it; it was for W. Pawlak. The Prime Minister of coalition Cabinet did not oppose to candidatures of Andrzej Milczanowski, Andrzej Olechowski, Piotr Kołodziejczyk; indirectly he accepted the concept of L. Wałęsa concerning the so called later the "the presidential departments." The coalition agreement favoured such practices ; only some departments were to be appointed from party key, the rest by those with high professional qualifications and who accept the coalition programme. ${ }^{109}$ Mutual mistrust of members coalitions favoured L. Wałęsa. They preferred to accept ministers from the head of state than reach compromise concerning their candidatures. But the relations of the head of state with the Cabinet could not be good. According to L. Wałęsa the conflict was inevitable. ${ }^{110}$

107 See: Stenographic report from the $2^{\text {nd }}$ Sejm sitting on November 10, 1993, p. 71.

108 Z. Szeliga, Rada Ministrów a Sejm 1989-2009, Lublin 1998, p. 33.

109 See: Coalition agreement from 1993 signed by W. Pawlak and Aleksander Łuczak (PSL) and Włodzimierz Cimoszewicz and Aleksander Kwaśniewski for SLD.

110 See: L. Wałęsa, Droga do prawdy..., p. 432. 


\section{THE CABINET OF JÓZEF OLEKSY}

Conflicts in coalition, numerous crises, including personal ones, and L. Wałęsa's activity led the SLD-PSL coalition to the decision of changing the cabinet. 11 "Polityka" commented: "Here two processes overlapped. Disputes inside the coalition itself and the attack of the opposition on the Prime Minister Pawlak and PSL government policy. So the criticism from Wałęsa’s part could be fruitful. Unfortunately we mixed all the priorities. The most important were the matters inside the coalition and not attempts to control, not constitutional attempts of the president, which were very important for the future of Polish democracy." 112

SLD opted for the reconstruction of the Cabinet. On February 7, 1991 A. Kwaśniewski at the meting of the leaders of SLD and PSL announced that he did not exclude the possibility of removing the Left from the Cabinet if there would be no changes in this organ. Then PSL unexpectedly proposed J. Oleksy, the Speaker, for the prime minister; Józef Zych was to become the Speaker. This concept surprised all, including the opposition that opted for the government of professionals. ${ }^{113}$ "J. Oleksy at the beginning of this term was the Speaker and held his duty in such a way that the rank of the Sejm rose - said Wiesław Skrzydło. He was valued and dexterous politician with great experience, respected in parliamentary circles."114 SLD agreed on PSL's offer. The news that J. Oleksy would become the prime minister quickly reached the media. J. Oleksy said that in this situation he could do nothing else but accept the post of the prime minister. ${ }^{115}$

On March 1, 1995 the Sejm voted over the non-confidence vote for the cabinet of W. Pawlak. The result was as follows: 285 deputies were for,

111 W. Sokół, Rząd Waldemara Pawlaka, [in:] Gabinety koalicyjne w III RP, ed. W. Jedynaka, Wrocław 2004, p. 151; J. Baczyński, Przypadek Waldemara P., "Polityka", February 18, 1995, no. 7, p. 3.

112 Premier z poświęcenia... Janina Paradowska i Wiesław Władyka w wywiadzie z Józefem Oleksym, "Polityka”, March 11, 1995, no. 10, p. 3.

113 J. Paradowska, Roszada zamiast mata, "Polityka”, February 18, 1995, no. 7, p. 3.

114 W. Skrzydło, Rząd Józefa Oleksego, [in:] Gabinety koalicyjne w III RP..., pp. 155-156.

115 Premier z poświęcenia..., p. 3. 
5 were against 127 abstained from voting. ${ }^{116} \mathrm{~W}$. Pawlak resigned. The head of state appointed J. Oleksy for the post of the Prime Minister who resigned from the post of a Speaker. He was the first Prime Minister from the Left in the history of the $3^{\text {rd }}$ Republic of Poland.

The Prime Minister aimed at large independence in deciding about personal composition of his Cabinet. It was not an easy task because his attempts were limited by the requirements of coalition parties. ${ }^{117}$

Besides, there was also the problem of so called president's departments.

Before he was asked to form the Cabinet he had met L Wałęsa to discuss the appointments in MSW, MON, MSZ. President's spokesman said that it would be an infringement of president's constitutional rights if SLD and PSL tried to give an opinion concerning his candidates. ${ }^{118} \mathrm{~L}$. Wałęsa said that J. Oleksy declared a cooperation with the head of state. During first conversation there were determined some decisions which the prime minister would not fulfill in the future. According to former president "Oleksy said that president's prerogatives were undeniable for all and he would accept them. He assured that he understood my intentions and that he would consult me in strategic matters. (...) I quickly understood that they were only empty slogans. The Prime Minister was doing what was good for him and his coalition." 119 The President demanded the post of the Ministry of Defence for Zbigniew Okoński and Ministry f Foreign Affairs for Andrzej Olechowski (probably without his consent). ${ }^{120}$ There were some opinion that the head of state wanted Andrzej Ananicz for this post. ${ }^{121}$ The coalition took into consideration president's suggestions concerning the strategic departments. Z. Okoński became the head of Ministry of Defence. ${ }^{122}$ A. Milczanowski (who was regarded as Wałęsa's

116 See: Stenographic report from the $44^{\text {th }}$ Sejm sitting on March 1, 1995, p. 25.

117 W. Skrzydło, Rząd Józefa Oleksego..., pp. 158-161.

118 G.S. , M.U. , J.C. , Prezydent broni swoich resortów. Spotkanie Wałęsa-Oleksy, "Rzeczpospolita", February 17, 1995, no. 41, pp. 1-2.

119 L. Wałęsa, Droga do prawdy..., p. 442.

120 J. Paradowska, Roszada..., p. 3.

121 W. Jedynaka (ed.), Gabinety koalicyjne w III RP, Wrocław 2004, p.170.

122 Z. Okoński described Wałęsa's attempts concerning cabinet formation: "(...) At the beginning I said that I had indirectly answered the question and that I was not here as the candidate of the coalition sensu stricto. It is known that ma $r$ President has been 
man) became the head of Ministry of Internal Affairs. He was the minister of MIA in H. Suchocka and W. Pawlak's cabinets. Władysław Bartoszewski became the head of Ministry of Foreign Affairs. Although the Prime Minister accepted the concept of L. Wałęsa he did not fully agree with this. He touched the problem of "president's departments" in his speech "there is no place for divisions into so called president's departments or into ministry of this or that party." 123 According to J. Oleksy recommendation of the head of state does not release the ministers from being loyal to the prime minister. "Mr President thinks that if he appoints his candidate on the post, he will get a full control of it. I think that he also takes responsibility for them." 124 On March 4, 1995 the Sejm voted over the Cabinet. The Cabinet was supported by 272 deputies, 99 were against, 13 abstained from voting. ${ }^{25}$ The new Cabinet was accepted by $71 \%$ of voters.

forcing my candidature for 3 months and loyalty does not allow me to oppose him. I personally, am in a very comfortable situation because I am not going to decide. $\mathrm{Mr}$ President will now argue with the Sejm, he may not sign or maybe veto etc. It will be your argument with mr. President (...)". See. Bulletin of the Committee of National Defence, no 1352/II term, Sejm Office p. 15.

123 Expose of the prime minister. Text of the speech of Józef Oleksy in Parliament, March 3, 1995, “Government Review" 1995, no. 3-4, p. 12.

124 Premier z poświęcenia...

125 See: Stenographic report from the $44^{\text {th }}$ Sejm sitting on March 4, 1995, p. 251. 
From this short, synthetic review of participation of Presidents in cabinet formation in 1989-1995 results that W. Jaruzelski was fully loyal towards processes of democratic changes in Poland. The position of the first, in the history of Third RP, head of state was weakened by fiasco of C. Kiszczak mission of government formation; the politician indicated by the President appeared ineffective. But W. Jaruzelski accepted C. Kiszczak failure with dignity and he engaged himself in the process of formation of T. Mazowiecki cabinet although he had constitutional instruments to block it."President Jaruzelski, Siwicki (Ministry of Defence) and I spread a protective umbrella over this Cabinet against "hardliners « in Poland and abroad."126 L. Wałęsa, benefiting from social consent, very actively took part in the process of formation of solidarity cabinets both before and after he became the head of state. He, with the substantive help of his closest and most trusted associate - prof Lech Falandysz - forced through a favourable for himself interpretation of art 61 of Small Constitution. Because of this, ministers from MoD, MIA, MFA in Pawlak and Oleksy's Cabinets were appointed by the head of state. It should be stressed that L. Wałęsa helped to promote two prominent politicians: J.K Bielecki and W. Pawlak.

126 Czesław Kiszczak, wicepremier, minister spraw wewnętrznych, [in:] Rzad Tadeusza Mazowieckiego, "Rzeczpospolita”, December 11-12, 199, no. 213, p. 4. 